\title{
Eser Elementler ile Diabetes Mellitus Komplikasyonları Arasındaki İlişki
}

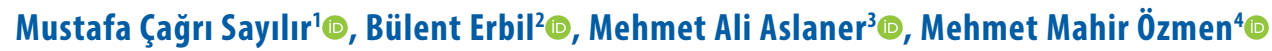

'Dışkapı Yıldırım Beyazıt Eğitim ve Araştırma Hastanesi, Acil Tıp, Ankara, Türkiye

${ }^{2}$ Hacettepe Üniversitesi Tıp Fakültesi, Acil Tıp, Ankara, Türkiye

${ }^{3}$ Gazi Üniversitesi Tıp Fakültesi , Acil Tıp, Ankara, Türkiye

${ }^{4}$ Liv Hospital, Genel Cerrahi, Ankara, Türkiye

Mustafa Çağrı Sayılır, Dr. Bülent Erbil, Dr.

Mehmet Ali Aslaner, Dr. Mehmet Mahir Özmen, Dr.

İletişim:

Dr. Mehmet Ali Aslaner

Gazi Üniversitesi Tıp Fakültesi, Acil

Tip, Ankara, Türkiye

Tel: +903122025051

E-Posta: maliaslaner@hotmail.com

Gönderilme Tarihi : 06 Mayıs 2019

Revizyon Tarihi : 11 Temmuz 2019

Kabul Tarihi : : 27 Temmuz 2019
ÖZET

Amaç: Glikoz metabolizmasında eser elementlerin (çinko (Zn), krom (Cr), selenyum (Se), demir (Fe), bakır (Cu) ve vanadyum (Va)) etkileri olduğu bilinmektedir. Bu çalışmanın amacı acil servise başvuran hastalarda eser element düzeyleri ile akut diabetes mellitus (DM) komplikasyonları arasındaki ilişkiyi tespit etmektir.

Yöntemler: Bir üniversitesi hastanesi üçüncü basamak acil servisine 01 0cak 2012 - 29 Şubat 2012 tarihleri arasında başvuran 18 yaş ve üzeri yeni DM tanısı konulan veya daha önceden DM tanısı olan hastalar aydınlatıımış onam alınarak çalışmaya dâhil edildi. Kontrol Grubu ise bilinen herhangi bir hastalığı ve ilaç kullanımı olmayan 18 yaş üstü sağlıkı bireylerden seçildi. Eser element düzeyleri ise atomik absorpsiyon spektrofotometrik yöntemle TQ X5 marka ICP-MS cihazı kullanılarak elde edildi. Eser element düzeyleri, hem DM ile sağlıklı kontrol grubu arasında hem de DM komplikasyonları olan hastalar ile sağıkılı kontrol grubu arasında karşılaştırıldı.

Bulgular: Çalışmaya toplamda 249 (124 kadın) kişi alındı. 151 (84 kadın) kişi çalışma grubunu (DM) oluştururken 98'i (40 kadın) kontrol grubunu oluşturdu. Acil servise başvuran diyabet hastalarııı ölçülen eser element düzeyleri ile kontrol grubu karşılaştırıldığında ortalama değerlerde belirgin bir fark olmadığı tespit edildi ( $p>0,05)$. Akut diyabetik komplikasyonları olan (diyabetik ketoasidoz, diyabetik ketoz ve hiperglisemi) hastalar $(\mathrm{n}=11)$ ile kontrol grubu karşılaştırıldığında da yine her iki grup arasında anlamlı fark bulunamadı $(p>0,05)$.

Sonuç: Yapılan araştırmalar eser elementlerin moleküler düzeyde glikoz metabolizmasındaki etkilerini göstermekle birlikte, çalışmamızda acil servise başvuran akut diyabetik komplikasyonları olan hastalarda bakılan eser element düzeylerinin (Zn, Cr, Se, Fe, Cu ve Va) sağlıklı bireylerle karşılaştırılması sonucunda aralarında anlamlı bir fark bulunamamıştır.

Anahtar sözcükler: Diabetes mellitus, eser element, çinko, krom, selenyum, demir, bakır, vanadyum

\section{THE RELATIONSHIP BETWEEN TRACE ELEMENTS AND COMPLICATIONS OF DIABETES MELLITUS}

\section{ABSTRACT}

Objectives: The effect of trace elements (zinc ( $\mathrm{Zn}$ ), chromium (Cr), selenium (Se), iron (Fe), copper (Cu), vanadium (Va)) on the glucose metabolism is known. The aim of this study was to determine the relationship between trace element levels and acute diabetes mellitus (DM) complications in patients presented to the emergency department (ED).

Patients and Methods: Patients presented to the ED of a university hospital between January and February 2012 over the age of 18 with newly or previously diagnosed DM, were included in the study. The control group was selected from healthy individuals over the age of 18 without any known disease or drug use. Trace element levels were obtained by the atomic absorption spectrophotometric method using the TQ X5 ICP-MS device. Trace element levels were compared between DM and control group as well as between DM complications and control group.

Results: A total of 249 (124 female) patients were included in the study. 151 (84 women) were in the study group and 98 (40 women) in the control group. When the measured trace element levels of the diabetic patients were compared with those of the control group, there was no significant difference in the mean values $(p>0.05)$. There was also no significant difference between patients ( $n=11$ ) with acute diabetic complications (diabetic ketoacidosis, diabetic ketosis and hyperglycemia) and the control group ( $p>0.05$ ).

Conclusion: In this study, no significant difference was found between the trace element levels of the diabetic complications group and those of the control group.

Keywords: Diabetes Mellitus, trace element, zinc, chromium, selenium, iron, copper, vanadium 
D iabetes mellitus (DM) genellikle kalıtımsal ve çevresel etkenlerin birleşimi ile ortaya çıkan, insülin salınımının veya insülinin etkisinin veya her ikisinin birden bozukluğu sonucu oluşan, hiperglisemi ile karakterize bir grup metabolik hastalıktır. Diabetes mellitus hastalığında hiperglisemi, hastalığın morbiditesini ve mortalitesini arttıran akut ya da kronik nedenlerden sorumludur. Glikoz metabolizmasının ise eser elementler ile arasında ilişki olduğu bilinmektedir (1). Innsülin etkisinin krom, magnezyum, vanadyum, çinko, manganez, molibden ve selenyum gibi eser elementler tarafından arttırıldığı gösterilmiştir (2).

Çinko (Zn), insülin metabolizmasındaki yüzlerce enzimin fonksiyonu üzerinde etkili antioksidan olarak görev yapan bir eser elementtir (3-5). Zn, insülin hekzamerlerinin sabitlenmesinde ve insülinin pankreasta stoklanmasında önemli bir rol oynaması nedeniyle insülin direncinin ve diyabetin ilerlemesinde önemli bir faktör olabilir (6-8). Tip 1 diyabet hastalarında yapılan çalışmalarda ise Zn düşüklüğü ile pankreatik hasar arasında doğru orantı olduğu gösterilmiştir (9). Bu çalışmalarla birlikte obez hastalarda azalmış Zn değerleri ile artmış insülin direncinin birlikte olduğu gösterilmiştir (10).

Glikoz metabolizmasının düzenlenmesinde krom $(\mathrm{Cr})$ elementinin önemli bir yeri vardır. Yapılan çalışmalarda $\mathrm{Cr}$ eksikliğinde, bozulmuş glikoz toleransı, açlık hiperglisemisi ve lipit bozuklukları ortaya çıkmıştır $(11,12)$. Yapılan çalışmalar, Cr'un insülinin reseptör ve reseptör sonrası sinyalizasyonunu hormona duyarlı GLUT4 taşıyıcıları üzerinden etkileyerek glikozun taşınmasında etki gösterdiğini ortaya koymuştur. Üzerinde araştırma yapılan $\mathrm{Cr}$ derivelerinden $\mathrm{Cr}$-pikolinatın AMPKinaz ve p38 MAPkinaz aktivitelerinde artma, reseptör fosforilasyonunda artma ve insülin reseptör mRNA'sında artma (GLUT4 için mRNA, glikojen sentaz ve UCP3) gibi çeşitli etkilere neden olduğu gösterilmiştir (13-15).

In vitro olarak selenyum (Se) P38MA fosfokinaz üretimini azaltarak hiperglisemi ve adhezyon molekül salınımına bağlı gelişen hiperinsülinemiyi azaltır. Bununla birlikte inflamasyonu azaltarak Nuclear Factor-KappaB (NFkB), CRP ve L-Selektin yapımını azaltır $(16,17) .9000$ Amerikalı üzerinde yapılan bir araştırmada artmış Se seviyeleri ile birlikte artmış diyabet oranı görülmektedir $(18,19)$.

Vanadyum (Va) antidiyabetik özelliğe sahip olan bir eser elementtir. Bu özelliği yaklaşık yüz yıldır bilinmektedir (20). Va, insülin reseptör sinyal yolunda insülin benzeri etki göstererek glikoz metabolizmasında rol oynar (21). Hakkında en fazla kanıt gösterilen etkisi IRS-1, PKB, GSK3 ve FOXO1 komplekslerinin fosforilasyonunu arttırarak fosfotirozin fosforilaz inhibisyonunu sağlamasıdır $(22,23)$. Yapılan başka bir çalışmada diyabetik sıçanlarda karaciğerde glikokinaz aktivitesini arttırıcı özelliği olduğu gösterilmiştir. İnsülin benzeri etkileri ise daha çok GLUT4 üzerinden görülmektedir (24). Bu durum insülin direnci görülen durumlarda Va desteği verildiğinde az da olsa ortaya çıkan normoglisemik durumları açıklamaktadır $(25,26)$.

Sistemik demir (Fe) miktarındaki artış ile bozulmuş glikoz metabolizması arasındaki ilişki ilk olarak herediter hemokromatozis hastalarında artmış diyabet sıklığı üzerine yapılan çalışmalarda ortaya çıkmıştır (27). Fe birikimi sonrası diyabet gelişmesi, flebotomi veya Fe çelasyon tedavisi sonrası glisemik kontrolün düzelmesi Fe'in diyabet gelişimine neden olduğunu düşündürmektedir $(28,29)$. Hemokromotozisli fare modellerinde artmış Fe ve oksidatif stres sonucu pankreatik hücrelerde apopitozis ve bu nedenle de azalmış insülin miktarı görülmektedir (30).

Bakır (Cu) eksikliğinin diyabetin başlangııında etkili olduğunu gösteren net kanıtlar ortaya halen konulamamıştır (31). Yapılan bir çalışmada farelerde streptozotosin ile meydana getirilen Tip 1 diyabetin Cu desteği ile (oksidatif stres reaksiyonlarını baskılayarak) engellendiğine yönelik kanıtlar vardır (32).

Eser elementler ile diyabet arasında bir ilişki olduğu bilinmektedir. Ancak diyabet komplikasyonları ile eser element ilişkisi net değildir. Bu nedenle bu çalışmada, acil serviste hastaların kanda eser element düzeylerini ölçerek, eser elementler ve akut diyabetik komplikasyonları arasındaki ilişkiyi tespit etmek amaçlanmıştır.

\section{Yöntemler}

Bir üniversite hastanesi acil tıp anabilim dalı erişkin acil servisine 01 Ocak 2012-29 Şubat 2012 tarihleri arasında başvuran 18 yaş ve üzeri acilde yeni DM tanısı konulan veya daha önceden DM tanısı olan tüm hastalar aydınlatıımış onam alınarak çalışmaya dâhil edildi. Bu hastalar içerisinde diyabetik komplikasyonları olanlar ayrıca değerlendirmeye alındı. Kontrol grubu ise hikâyesinde bilinen herhangi bir hastalığı ve ilaç kullanımı olmayan 18 yaş üstü sağlıklı bireylerden seçildi. Dosyalarına ulaşılamayan, dosya bilgileri eksik olan, laboratuvar değerleri eksik olan hastalar çalışma grubuna dâhil edilmedi. Çalışma için klinik araştırmalar etik kurulunun $03-80-12$ sayı ve 13 Şubat 2012 tarihli etik kurul onayı alındı.

Hastaların ve kontrol grubunun eser element düzeyleri atomik absorpsiyon spektrofotometrik yöntemle TQ X5 marka ICP-MS cihazı kullanılarak elde edildi. Akut komplikasyon; diyabetik ketoasidoz, diyabetik ketoz ve hiperglisemi (açlık plazma glikozu $\geq 126 \mathrm{mg} / \mathrm{dL}$ ) olarak tanımlandı. Hastalardan ve kontrol grubundan gönüllü olduklarına dair onam formu alınmıştır. 


\section{Istatistiksel Analiz}

Elde edilen veriler hazırlanan forma kaydedildi ve SPSS 15,0 (SPSS Inc., IL, Chicago, USA) paket programı kullanılarak istatiksel analizi yapıldı. Tanımlayıcı istatistiklerden sayısal ölçümler için ortalama (standart sapma) ve yüzde kullanıldı. Verilerin normal dağılım gösterip göstermediği Kolmogorov-Smirnov testi ile değerlendirildi. Normal dağılım gösteren ölçümler için hasta ve kontrol grubunda eser element karşılaştırılmasında bağımsız gruplarda $t$ testi; normal dağılım göstermeyen ölçümler için ise MannWhitney $\mathrm{U}$ testi kullanıldı. Hasta ve kontrol grubunda yaş dağılımı farklı olduğundan; eser element karşılaştırmaları yaşa göre düzeltme yapıldıktan sonra regresyon analizi ile elde edildi. İstatistiksel analizlerin tümünde $p<0,05$ anlamlı olarak kabul edildi.

\section{Bulgular}

Çalışmaya toplamda 249 (124 kadın) kişi alındı. 151 (84 kadın) kişi çalışma grubunu oluştururken 98'i (40 kadın) kontrol grubunu oluşturdu.

Diyabet hastalığı tanısı olup acil servise başvuran hastaların yaş ortalaması 63,74 ( $\mathrm{min}=22$, maks=93) yıl, kontrol grubundaki kişilerde ise yaş ortalaması 30,29 ( $\min =23$, maks=55) yıl olarak tespit edildi. (Şekil 1)

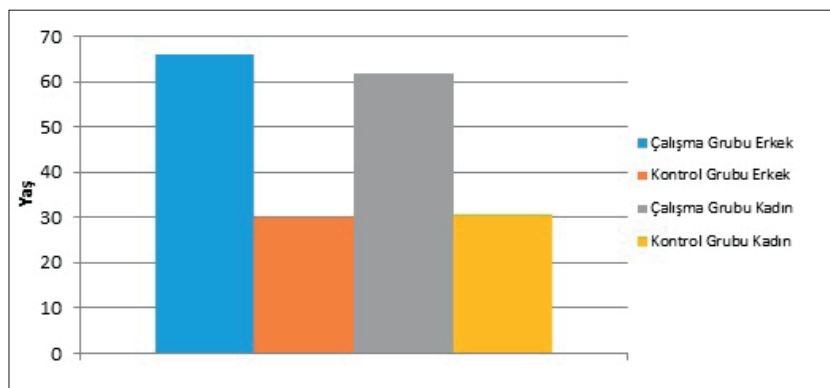

Şekil 1. Çalışmaya alınan grupların yaş ortalaması.

Acil servise başvuran diyabetik olgular ile kontrol grubunun eser element değerleri Tablo 1 ve Şekil 2'de verilmiştir. Acil servise başvuran diyabet hastalarının ( $n=151)$ ölçülen eser element düzeyleri ile kontrol grubu karşılaştırıldığında ortalama değerlerde belirgin bir fark olmadığı tespit edildi $(p>0,05)$. Yaşa ve cinsiyete göre düzeltilmiş basit regresyon analizi yapıldıktan sonra eser element düzeyleri ile ilişkili anlamlı $p$ değerleri elde edilmedi $(p>0,05)$.

Acil servise başvuran diyabetik hastalar içinde akut diyabetik komplikasyonları olan (diyabetik ketoasidoz, diyabetik ketoz ve hiperglisemi) hastalar $(n=11)$ ile kontrol grubu karşılaştırıldı (Tablo 2-Şekil 3). Karşılaştırma sonucu her iki grup arasında $p$ değeri açısından anlamlı fark bulunamadı $(p>0,05)$.
Tablo 1. Acil servise başvuran diyabetik olgular ile kontrol grubunun eser element değerleri

\begin{tabular}{lccccc} 
& $\begin{array}{c}\text { Kontrol grubu } \\
(\boldsymbol{n}=\mathbf{9 8}) \\
\text { Mean } \pm \text { SD }\end{array}$ & $\begin{array}{c}\text { Çalışma grubu } \\
(\boldsymbol{n}=\mathbf{1 5 1}) \\
\text { Mean } \pm \text { SD }\end{array}$ & $\boldsymbol{P}$ & $\boldsymbol{P 1}$ & $\boldsymbol{P 2}$ \\
\hline Se (mg/dL) & $112,51 \pm 60,40$ & $117,41 \pm 58,82$ & 0,545 & 0,808 & 0,613 \\
Zn (mg/dL) & $79,41 \pm 39,07$ & $78,27 \pm 39,21$ & 0,722 & 0,530 & 0,774 \\
Fe (mg/dL) & $73,91 \pm 32,42$ & $81,06 \pm 35,54$ & 0,193 & 0,285 & 0,091 \\
Cu (mg/dL) & $74,38 \pm 35,30$ & $77,36 \pm 36,22$ & 0,616 & 0,827 & 0,385 \\
Cr $(\mathbf{n m o l} / \mathbf{L})$ & $86,50 \pm 43,50$ & $93,19 \pm 42,97$ & 0,274 & 0,663 & 0,164 \\
Va $(\mathbf{n g} / \mathbf{m L})$ & $0,73 \pm 0,32$ & $0,81 \pm 0,35$ & 0,193 & 0,285 & 0,091 \\
\hline P.
\end{tabular}

$P$, yaşa göre düzeltilmemiş; $P 1$, yaşa göre düzeltilmiş; $P 2$, cinsiyete göre düzeltilmiş.

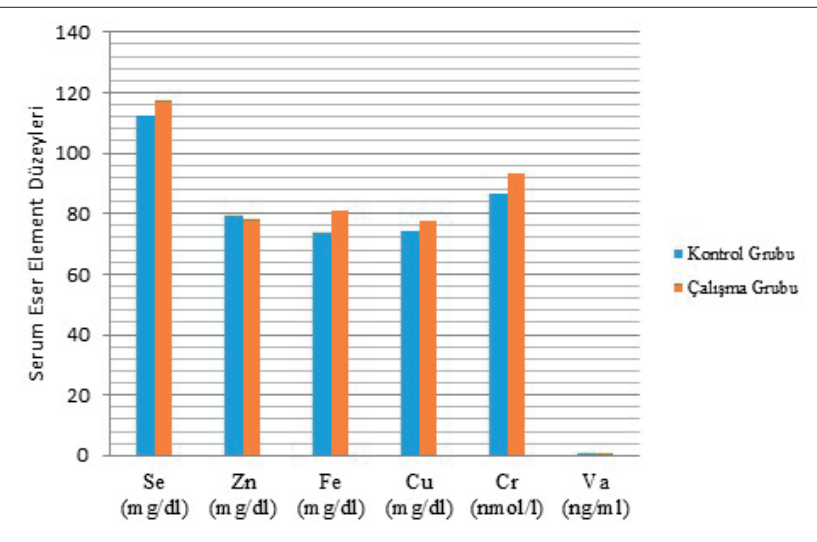

Şekil 2. Diyabetik olgular ile kontrol grubunun eser element değerleri.

Tablo 2. Akut komplikasyonlu (AK) olgularda eser element düzeyleri

\begin{tabular}{lccc} 
& $\begin{array}{c}\text { Kontrol grubu } \\
(\boldsymbol{n = 9 8 )} \text { Mean } \pm \text { SD }\end{array}$ & $\begin{array}{c}\text { Çalısma grubu } \\
(\boldsymbol{n = 1 1 )} \text { Mean } \pm \text { SD }\end{array}$ & $\boldsymbol{P}$ \\
\hline Se (mg/dL) & $112,51 \pm 60,40$ & $114,00 \pm 68,42$ & 0,868 \\
Zn (mg/dL) & $79,41 \pm 39,07$ & $76,00 \pm 45,61$ & 0,556 \\
Fe (mg/dL) & $73,91 \pm 32,42$ & $90,72 \pm 28,63$ & 0,076 \\
Cu (mg/dL) & $74,38 \pm 35,30$ & $85,18 \pm 19,67$ & 0,147 \\
Cr (nmol/L) & $86,50 \pm 43,50$ & $102,21 \pm 23,61$ & 0,103 \\
Va (ng/mL) & $0,73 \pm 0,32$ & $0,90 \pm 0,28$ & 0,760
\end{tabular}

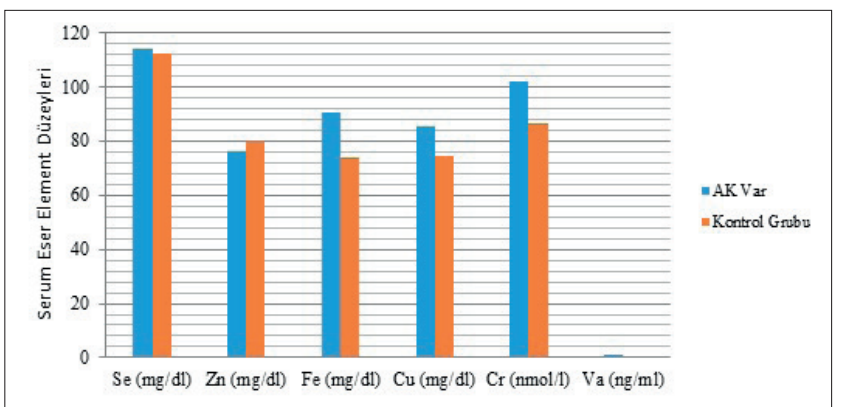

Şekil 3. Akut komplikasyonlu (AK) olgularda eser element düzeyleri. 


\section{Tartışma}

Glikoz metabolizmasında çinko (Zn) insülin hekzamerlerinin sabitlenmesinde ve insülinin pankreasta stoklanmasında önemli bir rol oynadığından insülin direncinin ve diyabetin ilerlemesinde önemli bir rolü olduğu düşünülmektedir (6-8). Serdar ve ark. tarafından 2009 yılında yapılan araştırmada insülin kullanmayan diyabetli hasta grubuyla ( $n=31)$ kontrol grubu $(n=22)$ karşılaştırılmış, bakılan Zn değerleri arasında fark bulunamamıştır (33). Yine Zargar ve ark. tarafından 1998 yılında insüline bağımlı olmayan diyabet hastaları üzerinde yapılan çalışmada $\mathrm{Zn}$ değerlerinde kontrol grubuna göre anlamlı bir değişiklik bulunamamıştır (34). Flores ve ark. tarafından 2011 yılında yapılan araştırmada bakılan serum $\mathrm{Zn}$ düzeyleri kontrol grubuna göre farklılık göstermemiştir (35). Bizim çalışmamızda da bu çalışmalarla paralel olarak her iki grupta serum Zn düzeyleri arasında fark bulunamamıştır.

Krom $(\mathrm{Cr})$, moleküler düzeyde insülin etkisinde ve glikoz transport mekanizmasında rol oynadığı için glikoz intoleransı, Tip 2 diyabet, gestasyonel diyabet ve steroidin indüklediği diyabetin tedavisinde faydalı olabileceği düşünülen bir eser elementtir (36). Açlık hiperglisemisi ve glikoz intoleransı görülen bireylerde laboratuvar çalışmalarında $\mathrm{Cr}$ eksikliğinin saptanması üzerine insülin direnci ve diyabette $\mathrm{Cr}$ takviyesinin etkisi de araştırılmaya başlanmıştır. Serum $\mathrm{Cr}$ değerleri diyabetik hastalarda normal bireylere göre $1 / 3$ oranında daha az bulunmuştur. Guan ve ark. tarafından yapılan araştırmada yüksek $\mathrm{Cr}$ içeren bira mayası ile beslenen domuzlarda glikoz toleransında düzelmenin olduğu fakat bazal glikoz düzeylerinde değişme olmadığı gösterilmiștir (37). Diyabetik hastaların Cr düzeyleri ile kontrol grubunun karşılaştırıldığı çalışmalarda $\mathrm{Cr}$ düzeyleri çalışma grubunda düşük bulunmuştur $(35,38$, 39). Bizim çalışmamızda ise her iki grupta serum $\mathrm{Cr}$ düzeyleri arasında fark bulunamamıştır.

Selenyum (Se) üzerine yapılmış çok sayıda araştırma bulunmamaktadır (21). Yapılan çalışmalarda Se'un diyabeti önlediğine dair net kanıtlar yoktur (17). Diyabetik hastalar ile kontrol grubu arasında serum Se düzeyleri arasında karşılaştırma yapılan çalışmalarda anlamlı değerlere rastlanmamıştır $(35,40)$. Bizim çalışmamızda ise her iki grupta Se düzeyleri arasında fark bulunamamıştır.

Yapılan hayvan deneylerinde orta veya şiddetli diyabet olgularında Vanadyum (Va) tuzlarının etkili olduğu gösterilmiștir. Vanadyum sülfat ya da bis (maltolato) oksovanadyumun Tip 1 ve Tip 2 diyabet modellerinde etkili olduğu kanıtlanmıştır $(24,26)$. Hastaların tedavisinde organik Va tuzlarının kullanılmasının yeni bir yol olarak geliştirilmesi önemli olabilecek bir gelişmedir. İnsanlar üzerinde de birçok çalışma yapılmıştır fakat bu çalışmalar kısa süreli olup sınırlı sayıda hasta üzerinde gerçekleştirilmiştir (41). Flores ve ark. tarafından yapılan çalışmada kontrol grubunda Va düzeyi diyabetik hasta grubuna göre anlamlı yüksek bulunmuştur (35). Bizim çalışmamızda ise her iki grupta Va düzeyleri arasında fark bulunamamıştır.

Demirin (Fe) indüklediği diyabet olgularında elde edilen veriler açık değildir. Bu veriler daha çok hayvan deneyleri üzerinden elde edilmiştir (27). Çalışmalarda diyetle artmış Fe alımının ve artmış serum ferritin düzeylerinin diyabet gelişimi açısından risk oluşturduğu gösterilmiştir (42-44). Özellikle gebelikte artan oral Fe alımının gestasyonel diyabet gelişiminde rol oynadığını düşündüren çalışmalar vardır (45-47). Bunun sebebi, gebelikte kanda artan oksijen miktarının ve yüksek dozlarda oral Fe replasmanının serbest oksijen radikallerinin yapımına zemin hazırlayarak pankreatik hücre yıkımı ve insülin salınımında azalmaya yol açmaları olabilir. Özetle Fe birikimi ve Fe'in neden olduğu oksidatif stres $\beta$-hücrelerinde apopitoz, karaciğer fonksiyon bozukluğu ve insülin direnci ile tip 2 diyabetin patogenezine katkıda bulunur (48). Bizim çalışmamızda ise her iki grupta Fe düzeyleri arasında fark bulunamamıştır.

Bakır (Cu) eksikliği genelde vücutta kardiyovasküler hastalıkların artışı ile birlikte ortaya çıkmaktadır (49). Cu eksikliğinin sistemik etkileri yüksek kan basıncı, inflamasyon, anemi, azalmış kan pıhtılaşması ve damar tıkanıklığında artış olarak ortaya çıkmaktadır (31). Diyabetik hastalar ve yapay olarak diyabet geliştirilmiş kobay hayvanlarında Cu şelatörü olan trietine tedavisi uygulandığında kalp fonksiyonlarında iyileşme (50) ve bununla birlikte kobay hayvanlarında diyabete bağlı göz komplikasyonlarından korunmanın gerçekleştiği gösterilmiştir (51). Yapılan bu çalışmalardan Cu'ın patogenez yerine daha çok komplikasyonların tedavisinde kullanılabileceği akla gelmektedir. İnsanlar ve kobaylar üzerinde yapılan bazı karşılaştırma çalışmalarında diyabetik vakaların serumlarında Cu düzeyi yüksek bulunmuştur $(34,35,39,52)$. Bu çalışmalara karşılık Tip 2 diyabeti olan genç hastalar üzerinde yapılan çalışmada ise serum Cu düzeyi kontrol grubuna göre düşük bulunmuşken (38), Tip 1 diyabetli hastalar üzerinde yapılan çalışmada ise $\mathrm{Cu}$ düzeylerinde kontrol grubuna göre değişikliğe rastlanmamıştır (53). Bizim çalışmamızda ise her iki grupta bakır düzeyleri arasında fark bulunamamıştır. 


\section{Sonuç}

Literatür verileri eser elementlerin moleküler düzeyde glikoz metabolizmasındaki etkilerini göstermekle birlikte, klinikte tedavi amacıyla kullanılması için yapılan araştırmalar sınırlı düzeydedir. Eser elementlerin uzun dönem replasman tedavisi olarak verilmeleri sonrasında glikoz

\section{Kaynaklar}

1. Murray R, Mayes PA, Rodwell VW, Granner DK. Harper's Biochemistry 25th ed. Appleton \& Lange; 2000.

2. Candilish DJE. Minerals. J Am Coll Nutr 2000;17:286-310. http:// www.nutrition-matters.co.uk/free_docs/tracelements.htm

3. Haase $\mathrm{H}$, Overbeck S, Rink L. Zinc supplementation for the treatment or prevention of disease: current status and future perspectives. Exp Gerontol 2008;43:394-408. [CrossRef]

4. Saper RB, Rash R. Zinc: an essential micronutrient. Am Fam Physician 2009;79:768-72. https://www.ncbi.nlm.nih.gov/pmc/articles/ PMC2820120/

5. Walsh CT, Sandstead HH, Prasad AS, Newberne PM, Fraker PJ. Zinc: health effects and research priorities for the 1990s. Environ Health Perspect 1994;102:5-46. [CrossRef]

6. Kaneto H, Katakami N, Matsuhisa M, Matsuoka TA. Role of reactive oxygen species in the progression of type 2 diabetes and atherosclerosis. Mediators Inflamm 2010;2010:453892. [CrossRef]

7. Prasad AS. Clinical, immunological, anti-inflammatory and antioxidant roles of zinc. Exp Gerontol 2008;43:370-7. [CrossRef]

8. Wiernsperger NF. Oxidative stress as a therapeutic target in diabetes: revisiting the controversy. Diabetes Metab 2003;29:579-85. [CrossRef]

9. Chausmer AB. Zinc, insulin and diabetes. J Am Coll Nutr 1998;17:10915. [CrossRef]

10. Suliburska J, Bogdanski P, Pupek-Musialik D, Krejpcio Z. Dietary intake and serum and hair concentrations of minerals and their relationship with serum lipids and glucose levels in hypertensive and obese patients with insulin resistance. Biol Trace Elem Res 2011;139:137-50. [CrossRef]

11. Goldhaber SB. Trace element risk assessment: essentiality vs. toxicity. Regul Toxicol Pharmacol 2003;38:232-42. [CrossRef]

12. Wallach S. Clinical and biochemical aspects of chromium deficiency. J Am Coll Nutr 1985;4:107-20. [CrossRef]

13. Wang $Y Q$, Yao MH. Effects of chromium picolinate on glucose uptake in insulin-resistant 3T3-L1 adipocytes involve activation of p38 MAPK. J Nutr Biochem 2009;20:982-91. [CrossRef]

14. Wang $\mathrm{H}$, Kruszewski $\mathrm{A}$, Brautigan DL. Cellular chromium enhances activation of insulin receptor kinase. Biochemistry 2005;44:8167-75. [CrossRef]

15. Qiao W, Peng Z, Wang Z, Wei J, Zhou A. Chromium improves glucose uptake and metabolism through upregulating the mRNA levels of IR, GLUT4, GS, and UCP3 in skeletal muscle cells. Biol Trace Elem Res 2009;131:133-42. [CrossRef]

16. Zheng HT, Zhou LN, Huang CJ, Hua X, Jian R, Su BH, Fang F. Selenium inhibits high glucose- and high insulin-induced adhesion molecule expression in vascular endothelial cells. Arch Med Res 2008;39:3739. [CrossRef]

17. Stranges S, Marshall JR, Natarajan R, Donahue RP, Trevisan M, Combs $G F$, et al. Effects of long-term selenium supplementation on the incidence of type 2 diabetes: a randomized trial. Ann Intern Med 2007;147:217-23. [CrossRef] regülasyonunda bir miktar iyileşme olduğu gösterilmiştir. Fakat bu tip tedavilerin acil serviste uygulanabilirliğinin zor olmasının yanı sıra, çalışmamızda acil servise başvuran diyabetik hastalarda bakılan eser element düzeylerinin ( $\mathrm{Zn}, \mathrm{Cr}, \mathrm{Se}, \mathrm{Fe}, \mathrm{Cu}$ ve Va) sağılıkı bireylerle karşılaştırılması sonucunda aralarında anlamlı bir fark bulunamamıştır.

18. Battin EE, Brumaghim JL. Antioxidant activity of sulfur and selenium: a review of reactive oxygen species scavenging, glutathione peroxidase, and metal-binding antioxidant mechanisms. Cell Biochem Biophys 2009;55:1-23. [CrossRef]

19. Laclaustra M, Navas-Acien A, Stranges S, Ordovas JM, Guallar E. Serum selenium concentrations and hypertension in the US Population. Circ Cardiovasc Qual Outcomes 2009;2:369-76. [CrossRef]

20. Thompson $\mathrm{KH}$, Orvig C. Vanadium in diabetes:100 years from Phase 0 to Phase I. J Inorg Biochem 2006;100:1925-35. [CrossRef]

21. Wiernsperger N, Rapin J. Trace elements in glucometabolic disorders: an update. Diabetol Metab Syndr 2010;2:70. [CrossRef]

22. Mehdi MZ, Pandey SK, Theberge JF, Srivastava AK. Insulin signal mimicry as a mechanism for the insulin-like effects of vanadium. Cell Biochem Biophys 2006;44:73-81. [CrossRef]

23. Vardatsikos G, Mehdi MZ, Srivastava AK. Bis (maltolato)oxovanadium (IV)-induced phosphorylation of PKB, GSK-3 and FOXO1 contributes to its glucoregulatory responses (review). Int J Mol Med 2009;24:303-9. [CrossRef]

24. Shafrir E, Spielman S, Nachliel I, Khamaisi M, Bar-On H, Ziv E. Treatment of diabetes with vanadium salts: general overview and amelioration of nutritionally induced diabetes in the Psammomys obesus gerbil. Diabetes Metab Res Rev 2001;17:55-66. [CrossRef]

25. Jacques-Camarena O, Gonzalez-Ortiz M, Martinez-Abundis E, LopezMadrueno JF, Medina-Santillan R. Effect of vanadium on insulin sensitivity in patients with impaired glucose tolerance. Ann Nutr Metab 2008;53:195-8. [CrossRef]

26. Poucheret $P$, Verma $S$, Grynpas MD, McNeill JH. Vanadium and diabetes. Mol Cell Biochem 1998;188:73-80. [CrossRef]

27. Swaminathan S, Fonseca VA, Alam MG, Shah SV. The Role of Iron in Diabetes and Its Complications. Diabetes Care 2007;30:1926-33. [CrossRef]

28. Fernandez-Real JM, Lopez-Bermejo A, Ricart W. Iron stores, blood donation, and insulin sensitivity and secretion. Clin Chem 2005;51:1201-5. [CrossRef]

29. Jiang R, Ma J, Ascherio A, Stampfer MJ, Willett WC, Hu FB. Dietary iron intake and blood donations in relation to risk of type 2 diabetes in men: a prospective cohort study. Am J Clin Nutr 2004;79:70-5. [CrossRef]

30. Cooksey RC, Jouihan HA, Ajioka RS, Hazel MW, Jones DL, Kushner JP, McClain DA. Oxidative stress, beta-cell apoptosis, and decreased insulin secretory capacity in mouse models of hemochromatosis. Endocrinology 2004;145:5305-12. [CrossRef]

31. Zheng Y, Li XK, Wang Y, Cai L. The role of zinc, copper and iron in the pathogenesis of diabetes and diabetic complications: therapeutic effects by chelators. Hemoglobin 2008;32:135-45. [CrossRef]

32. Sitasawad S, Deshpande M, Katdare M, Tirth S, Parab P. Beneficial effect of supplementation with copper sulfate on STZ-diabetic mice (IDDM). Diabetes Res Clin Pract 2001;52:77-84. [CrossRef]

33. Serdar MA, Bakir F, Hasimi A, Celik T, Akin O, Kenar L, et al. Trace and toxic element patterns in nonsmoker patients with noninsulindependent diabetes mellitus, impaired glucose tolerance, and fasting glucose. Int J Diabetes Dev Ctries 2009;29:35-40. [CrossRef] 
34. Zargar AH, Shah NA, Masoodi SR, Laway BA, Dar FA, Khan AR, et al. Copper, zinc, and magnesium levels in non-insulin dependent diabetes mellitus. Postgrad Med J 1998;74:665-8. [CrossRef]

35. Flores CR, Puga MP, Wrobel K, Garay Sevilla ME, Wrobel K. Trace elements status in diabetes mellitus type 2: possible role of the interaction between molybdenum and copper in the progress of typical complications. Diabetes Res Clin Pract 2011;91:333-41. [CrossRef]

36. Zhao P, Wang J, Ma H, Xiao Y, He L, Tong C, et al. A newly synthetic chromium complex-chromium (D-phenylalanine) 3 activates AMPactivated protein kinase and stimulates glucose transport. Biochem Pharmacol 2009;77:1002-10. [CrossRef]

37. Guan X, Matte JJ, Ku PK, Snow JL, Burton JL, Trottier NL. High Chromium Yeast Supplementation Improves Glucose Tolerance in Pigs by Decreasing Hepatic Extraction of Insulin. J Nutr 2000;130:1274-9. [CrossRef]

38. Basaki M, Saeb M, Nazifi S, Shamsaei H. Zinc, Copper, Iron, and Chromium Concentrations in Young Patients with Type 2 Diabetes Mellitus. Biol Trace Elem Res 2012;148:161-4. [CrossRef]

39. Kazi TG, Afridi HI, Kazi N, Jamali MK, Arain MB, Jalbani N, Kandhro GA. Copper, chromium, manganese, iron, nickel, and zinc levels in biological samples of diabetes mellitus patients. Biol Trace Elem Res 2008;122:1-18. [CrossRef]

40. Bleys J, Navas-Acien A, Guallar E. Serum selenium and diabetes in U. S. adults. Diabetes Care 2007;30:829-34. [CrossRef]

41. Smith DM, Pickering RM, Lewith GT. A systematic review of vanadium oral supplements for glycaemic control in type 2 diabetes mellitus. QJM 2008;101:351-8. [CrossRef]

42. Ashraf AP, Eason NB, Kabagambe EK, Haritha J, Meleth S, McCormick $\mathrm{KL}$. Dietary iron intake in the first 4 months of infancy and the development of type 1 diabetes: a pilot study. Diabetol Metab Syndr 2010;2:58. [CrossRef]

43. Forouhi NG, Harding AH, Allison M, Sandhu MS, Welch A, Luben R, et al. Elevated serum ferritin levels predict new-onset type 2 diabetes: results from the EPIC-Norfolk prospective study. Diabetologia 2007;50:949-56. [CrossRef]
44. Montonen J, Boeing $H$, Steffen A, Lehmann R, Fritsche A, Joost $\mathrm{HG}$, et al. Body iron stores and risk of type 2 diabetes: results from the European Prospective Investigation into Cancer and Nutrition (EPIC)-Potsdam study. Diabetologia 2012;55:2613-21. [CrossRef]

45. Bo S, Menato G, Villois P, Gambino R, Cassader M, Cotrino I, Cavallo-Perin P. Iron supplementation and gestational diabetes in midpregnancy. Am J Obstet Gynecol 2009;201:158.e1-6. [CrossRef]

46. Bowers K, Yeung E, Williams MA, Qi L, Tobias DK, Hu FB, Zhang C. A prospective study of prepregnancy dietary iron intake and risk for gestational diabetes mellitus. Diabetes Care 2011;34:1557-63. [CrossRef]

47. Qiu C, Zhang C, Gelaye B, Enquobahrie DA, Frederick IO, Williams MA. Gestational diabetes mellitus in relation to maternal dietary heme iron and nonheme iron intake. Diabetes Care 2011;34:1564-9. [CrossRef]

48. Rajpathak SN, Crandall JP, Wylie-Rosett J, Kabat GC, Rohan TE, Hu FB The role of iron in type 2 diabetes in humans. Biochim Biophys Acta 2009;1790:671-81. [CrossRef]

49. Cai L, Li XK, Song Y, Cherian MG. Essentiality, toxicology and chelation therapy of zinc and copper. Curr Med Chem 2005;12:2753-63. [CrossRef]

50. Cooper GJ, Phillips AR, Choong SY, Leonard BL, Crossman DJ, Brunton $\mathrm{DH}$, et al. Regeneration of the heart in diabetes by selective copper chelation. Diabetes 2004;53:2501-8. [CrossRef]

51. Hamada Y, Nakashima E, Naruse K, Nakae M, Naiki M, Fujisawa H, et al. A copper chelating agent suppresses carbonyl stress in diabetic rat lenses. J Diabetes Complications 2005;19:328-34. [CrossRef]

52. Tanaka A, Kaneto H, Miyatsuka T, Yamamoto K, Yoshiuchi K, Yamasaki $\mathrm{Y}$, et al. Role of copper ion in the pathogenesis of type 2 diabetes. Endocrine J 2009;56:699-706. https://www.jstage.jst.go.jp/article/ endocrj/56/5/56_K09E-051/_pdf

53. Zargar AH, Bashir MI, Masoodi SR, Laway BA, Wani Al, Khan AR, Dar FA. Copper, zinc and magnesium levels in type-1 diabetes mellitus. Saudi Med J 2002;23:539-42. http://citeseerx.ist.psu.edu/viewdoc/ download?doi=10.1 $1 \cdot 830.4185 \&$ rep $=$ rep $1 \&$ type $=$ pdf 